$$
\begin{gathered}
\text { Colloquia Litteraria } \\
\text { UKSW } \\
62009
\end{gathered}
$$

ŁUKASZ CYBULSKI

\title{
WYGODNA DEMAGOGIA? O PROBLEMACH METODY BADAŃ KAZNODZIEJSTWA W RZECZYPOSPOLITEJ OSKAR'̇ANYCH NARODÓW
}

Kaznodziejstwo nie doczekało się po dziś dzień rzetelnej, pełnej monografii. Podstawowym problemem jest przede wszystkim brak wnikliwych badań nad jego poszczególnymi grupami (pogrzebowe, weselne, obozowe i in.), co nie znaczy, że nie powstawały prace omawiające niektóre szczegółowe zagadnienia. Szczęśliwie zainteresowania kościelną sztuką mówniczą nie straciły aktualności wraz z zanikiem działalności badaczy, którzy kilkadziesiąt lat temu przyczynili się do rehabilitacji retoryki, a tym samym gatunków spychanych przez wiele lat na margines historii literatury, dziś dopiero wydobywanych z czytelniczego niebytu dzięki zainteresowaniu edytorów oraz specjalistów różnych dziedzin ${ }^{1}$.

Praca historyka na tym polu nie należy do łatwych, trzeba bowiem uwzględnić niemały materiał m.in. z dziedziny teologii, teorii i historii literatury, czego zresztą autor Rzeczypospolitej się nie wyrzeka. Jest to jednak przestrzeń, która stwarza możliwość dopuszczenia się różnych uchybień, których, niestety, nie udało się uniknąć.

Interdyscyplinarne studium Roberta Kościelnego przynosi analizę treściową tekstów sześćdziesięciu pięciu uznawanych za wybitnych i wpływowych, a tym samym najbardziej reprezentatywnych pod

\footnotetext{
1 Przykładem choćby rozprawy M. Trębskiej, Staropolskie szlacheckie oracje weselne. Genologia, obrzędy, źródła, Warszawa 2008; M. Skwary, O dowodzeniu retorycznym w polskich drukowanych oracjach pogrzebowych XVII wieku, Szczecin 1999; idem, Polskie drukowane oracje pogrzebowe XVII wieku. Bibliografia, Gdańsk 2010.
} 
względem realizacji wskazań Soboru Trydenckiego, przedstawicieli różnych środowisk siedemnastowiecznego kleru katolickiego. Stanowi ono nie tylko kontynuację badań nad obszernym wycinkiem prozy barokowej, lecz także otwiera ponownie dyskusję nad kulturowym podłożem sarmatyzmu, zagadnieniem, wydawać by się mogło, szczegółowo opisanym w przeciwieństwie do materiału kaznodziejskiego. W obliczu zaskakujących opinii różnych badaczy jakoby kaznodzieje w znacznym stopniu przyczynili się do sarmatyzacji szlachty, powyższa niewspółmierność staje się pobudką do przeprowadzenia analizy homiletyki siedemnastowiecznej pod kątem występowania treści, które mogły formować ów stan „wygodnej demagogii”2. Głównym celem, jaki stawia sobie autor Rzeczypospolitej oskarżanych narodów, jest falsyfikacja tego „obiegowego" i nie popartego faktyczną analizą treściową sądu o sarmatyzacji środowisk klerykalnych, które poprzez działalność kaznodziejską, będącą jednym z najsilniejszych środków ówczesnej propagandy, miały wpływać na kształtowanie negatywnych, charakterystycznych dla XVII wieku postaw szlachty. W tym celu historyk przedstawia zawarte w kazaniach opinie na temat przeszłości, teraźniejszości i przyszłości kraju, na temat szlachty, chłopów i kleru, jak również diagnozy i charakterystyki przyczyn upadku Rzeczpospolitej oraz wskazania sposobów jej wyjścia z zapaści. Kompozycja rozprawy oparta jest na czteroczęściowym podziale wynikającym z politycznej sytuacji kraju, nie uwzględnia natomiast wewnętrznej specyfiki rozwoju rzeczonego gatunku prozy, pozostawia też bez komentarza kwestię jego typologii i wszelkich konsekwencji z niej wynikających.

Charakterystyka sytuacji kaznodziejskiej i teorii kazania wypełnia jeden z początkowych rozdziałów publikacji. Autor słusznie zwraca tu uwagę na rozliczne trudności w nauczaniu kościelnym, do których należało między innymi dotarcie do najniższej klasy społecznej, jak również do szlachty. W pierwszym przypadku problem stanowiły kompetencje księży i audytorium na prowincjonalnych parafiach. Dowodem na próby przezwyciężenia tej trudności było tworzenie sieci kolegiów oraz szkół parafialnych, a także poświęcanie wiele uwa-

2 R. Kościelny, Rzeczypospolita oskarżanych narodów, Szczecin 2003, s. 12. 
gi kształceniu księży oraz kontroli ich pracy duszpasterskiej. Jest to przede wszystkim cenne świadectwo dbałości o kościelną ars praedicandi oraz wagi, jaką do niej przywiązywano ze względu na siłę oddziaływania. Drugi problem jawi się jako trudność dotarcia do wiernych, którzy, jak twierdzi Kościelny, nie czują potrzeby słuchania o swoich wadach: ,intencje nadawcy i odbiorców okazywały się rozbieżne”. Chociaż przypadek ten zdaje się być typowy dla „literatury zaangażowanej", ma on w tym miejscu szczególne znaczenie, gdyż może stanowić potwierdzenie słuszności postawionej przez autora tezy. Pytanie tylko, na ile jest to sytuacja typowa dla XVII wieku, na ile zaś dla kaznodziejstwa w ogóle, bez względu na to, do kogo kierowane są słowa upomnienia. Opis elementów teorii gatunku opiera się głównie na wypowiedziach pochodzących z końca XVI i początku XVII wieku, których autorami byli hierarchowie kościoła, oraz na stosownych uchwałach soboru. Analiza obejmuje jedynie zakres wyżej wymienionych treści, pomija natomiast wszystkie pozostałe, jak również właściwe każdemu z utworów okoliczności (kairos). W ten sposób badacz przyjmuje założenie, że istniał przede wszystkim jeden cel ogólnej „produkcji” homiletycznej - kształtowanie świadomości moralnej audytorium - ściśle związany z kościelnym programem nauczania, a zatem nie stanowiący novum w okresie potrydenckim. Stoi to w sprzeczności z podstawową zasadą retoryki (na której ars praedicandi się opierała) wykładaną w inventio: mówca musi każdorazowo uwzględniać okoliczności towarzyszące omawianemu zagadnieniu, jak również specyfikę audytorium, do którego należy dostosować to, jak się mówi i co się mówi. W tej sytuacji ciekawe jest, że autor przytacza wypowiedź Stanisława Karnkowskiego - który postuluje, aby „mówić według czasu, miejsca i osób” - nie wyciagając z niej stosownych wniosków. Najogólniej rzecz biorąc, trudno przyjąć pogląd jakoby wprawny mówca lekceważył opinio communis. Doskwiera również to, że wciąż nie mamy wglądu w materię zawartą $\mathrm{w}$ kompendiach teoretycznych, co z pewnością przyniosłoby wiele istotnych informacji na temat kształtu formalnego sermones. Mam na myśli przede wszystkim podniesioną $\mathrm{w}$ rozprawie kwestię prostoty.

3 op. cit., s. 30 . 
Otóż mówi się o niej przy okazji referowania potrydenckich założeń edukacyjnych, w myśl których nauczanie powinno obejmować tematykę swobodna, wykład podstawowych, prostych prawd moralnych czy, ogólnie, prawd koniecznych do zbawienia. Bez wątpienia jednak problem jest szerszy. Dotyczy również strony strukturalnej, owej „fabularyzacji”. Wątpliwości budzi zwłaszcza nacisk kładziony na prostotę, rozumianą również jako mówienie językiem zrozumiałym dla odbiorcy. Pomijam sprawę mowy ojczystej, która była dla protestantów jednym z przedmiotów sporu, by skupić się na formie artystycznej. Jaki jest stosunek owego wymogu prostoty, czyli tego, że „kapłan miał mówić jasno, zrozumiale dla wszystkich obecnych w świątyni" ${ }^{4}$, względem tendencji do komplikowania płaszczyzny kompozycyjnej i stylistycznej kazań z XVII wieku? Niewątpliwie miała ona służyć jako narzędzie „,do pomocy wiernym w przemianie obyczajów zgodnej z zaleceniami Ewangelii"s. Watpię jednak, aby chodziło tylko o bardziej przejrzyste wyłożenie prawd wiary czy uczynienie kazania „bliższym życia”. Owa „fabularyzacja” była przecież skutkiem zwiększenia nacisku na movere, które zajęło w barokowym myśleniu i działaniu retorycznym miejsce renesansowego inventio, jako lepiej służącemu perswazji. Chodziło więc zatem o efektywne wzbudzanie afektów, co usprawiedliwiano przekonaniem, że człowiek chętniej działa pod wpływem silnych emocji. Wszelkie zastrzeżenia odnośnie do wymogu prostoty rodzą się dlatego, że pochodzą od hierarchów, którzy na początku siedemnastego stulecia posiadali świadomość wieku minionego, zaś wskazania trydenckie nie wniosły wielu praktycznych zmian w tej materii.

Jeszcze jedna uwaga. Odnosi się ona do zawartego we wstępnych rozważaniach stwierdzenia: „,musimy założyć, że badane przez nas źródło było partytura, której mówca trzymał się w sposób mniej lub bardziej ścisły"6. Problem w tym, że wcale nie musimy; takie założenie wiele nie zmienia w postępowaniu badawczym, o ile mamy na myśli problem docierania treści kazań drukowanych do ludności niepi-

op. cit., s. 23.

ibidem.

6 op. cit., s. 37. 
śmiennej, co mogło odbywać się jedynie na drodze ustnego przekazu $\mathrm{z}$ ambony. Prawdę mówiąc, z punktu widzenia wierności wobec pisanego wzorca nie ma większego znaczenia, czy dany tekst został wygłoszony, czy nie, ponieważ każdy kaznodzieja miał prawo dokonywania kompilacji na własną rękę. Nie musiał w tym celu korzystać z tekstów siedemnastowiecznych. W grę wchodzą, oprócz dzieł z epoki, chociażby rozważania ojców kościoła, jak i wzorniki obcojęzyczne. Ponadto stan bibliotek mniejszych parafii wskazuje raczej na nieobecność tekstów analizowanych autorów niż na ich powszechne funkcjonowanie we wzmiankowanych środowiskach. Warto w tym miejscu zastanowić się nad tym, czy najprzedniejsi kaznodzieje swojego czasu - takich bierze pod uwagę Robert Kościelny - mieli faktycznie największy wpływ na kształt mentalności rozsianej po całej Polsce szlachty (wszak o szlachtę przede wszystkim chodzi). Po pierwsze, obieg książki drukowanej zmienił się drastycznie w przeciągu omawianego stulecia, w związku z czym utwory w ten sposób rozpowszechniane nie mogły oddziaływać z równą siłą w każdym okresie; odbiór nie był także jednakowo intensywny w poszczególnych regionach Królestwa Polskiego. W związku z powyższym recepcja poglądów wygłoszonych w danym roku, o ile w ogóle miała miejsce w najgłębszych zakątkach Rzeczpospolitej, mogła być, i zapewne była, znacznie opóźniona i nierównomierna. Po drugie, nie jestem przekonany, czy faktycznie kaznodzieje uznawani za wybitnych mieli przez całe stulecie największy wpływ na kształt opinii publicznej. Duże znaczenie księży funkcjonujących lokalnie musiało rosnąć wraz z decentralizacją państwa. Na ile poglądy przez nich głoszone odzwierciedlały tezy czołowych twórców?

Właściwa część publikacji, zawierająca wynik badawczych eksploracji historyka, podzielona jest na cztery rozdziały, odpowiadające dynamice rozwoju sytuacji społeczno-politycznej kraju: I - pierwsza połowa XVII w., II - lata 1648-1660, III - okres „czarnego ćwierćwiecza", IV - późny barok. Rozważania rozpoczyna stwierdzenie, że faktycznie szlachta żyjąca na początku nowego stulecia nie miała

7 Zob. chociażby K.J. Wojsznarowicz, Author do łaskawego czytelnika, [w:] idem, Orator polityczny różnym aktom pogrzebowym stużacy, Wilno 1644. 
wielu powodów do zmartwień, mogła w pełni cieszyć się swobodami i być dumna z odnoszonych zwycięstw. Podobnie było z przedstawicielami kleru, którzy odczuwali satysfakcję z powrotu znacznej części utraconych wiernych na łono Kościoła, co, ku powszechnemu zadowoleniu, odbyło się bez rozlewu krwi. Kaznodzieje nie ulegli jednak złudnym przejawom optymizmu, zachowując krytyczny stosunek do rzeczywistości, której negatywna ocena wypływała przede wszystkim z rzekomego upadku moralnego. Żadne bowiem zwycięstwo, żaden realny powód do radości nie są osiagnięciami na tyle wielkimi i trwałymi, by zwolniły człowieka z podejmowana trudu, jakim jest nieustanne baczenie na stan własnego sumienia. Każde zwycięstwo, $\mathrm{w}$ ich przekonaniu, pociaga za sobą ryzyko popadnięcia $\mathrm{w}$ pychę i zboczenia z drogi ku zbawieniu. Zdaniem historyka, to właśnie w tym przekonaniu, wyłuskanym pieczołowicie z licznych wypowiedzi, tkwi przyczyna ich niewrażliwości na różnego rodzaju względy wynikające z aktualnych okoliczności. Wiąże się z powyższym m.in. problem captatio benevolentiae, które, zdaniem Roberta Kościelnego „mogło przebiegać jedynie na płaszczyźnie formy, a nie treści”, gdyż

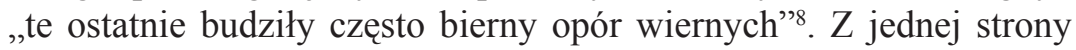
jest to przeoczenie zasady sztuki dobrego przemawiania, w myśl której prawdziwym mówca jest tylko ten, kto dostosowuje do audytorium nie tylko formę, lecz także i treść. Znów, trudno byłoby w tej sytuacji przyznać miano dobrego kaznodziei wielu wybitnym (przynajmniej pod względem artystycznym) twórcom, którzy w sposób zdecydowany głosili hasła odnowy moralnej, czy gorliwie zabiegali o pokorę i pokutną postawę wiernych. A przecież wśród takich postaci znajdują się niewątpliwie wielkie nazwiska. Z drugiej zaś strony, w myśl przytoczeń zamieszczonych w głównej części rozprawy, należałoby przychylić się do tezy, że zawartość ideologizacyjna czy raczej perswazyjna kazań barokowych sprowadzała się w głównej mierze do szeregu nagan i napomnień, które trwały przez całe siedemnastowiecze i nabierały jedynie dramatyzmu wraz z pogarszaniem się politycznej sytuacji państwa, faktycznie wykazując zaskakującą, ,niewrażliwość na, często istotne, zmienne historyczne zachodzące w ciągu interesujące-

\footnotetext{
8 R. Kościelny, op. cit., s. 14.
} 
go nas stulecia"9. Aby móc pozwolić sobie na jednoznaczne rozstrzygnięcie tego konfliktu, trzeba postawić pytanie o to, w jakim kierunku każdorazowo zmierzała persuasio, jakie miejsce zajmowały w niej napomnienia - czy były elementem kluczowym, czy też nie. Pozwoli to stwierdzić, czy zwracanie dużej uwagi na katalogi wad ludzkich jest praca, która daje nadzieję na realne korzyści badawcze.

$\mathrm{Z}$ prezentowanych przez ponad sto pięćdziesiąt stron cytatów wyłania się dość monotonny i jednobarwny ciąg utyskiwań i upomnień. Bez trudu można spostrzec, że mamy do czynienia z obiegowymi chwytami, które polegały na przywoływaniu chwalebnej przeszłości, minionego złotego wieku, w którym żyli poczciwi przodkowie, chylącej się ku upadkowi moralnemu teraźniejszości oraz, w późniejszym okresie, wstrząsającej, przesyconej katastroficznymi proroctwami przyszłości. Są to owe opisy czasu minionego, oceny teraźniejszego i prognozy przyszłego, zapowiedziane na wstępie. W związku z powyższym trudno wyzbyć się uporczywego wrażenia, że przez cały czas obcujemy z toposami. Zakres obserwacji badawczej nie objął jednak próby ich opisania, klasyfikacji ani objaśnienia celów (strategii oratorskich), w jakich każdorazowo były wykorzystywane, o czym świadczy choćby to, że bez słowa komentarza przytaczane są urywki kazań niedzielnych czy pogrzebowych, mogących realizować zupełnie odmienne typy dyskursów. Nie można owych klisz traktować dosłownie. W tym świetle dość niepoważnie brzmi stwierdzenie Roberta Kościelnego, (komentarz dotyczy cytatu z Kazania abo kolendy Fabriciusa): „«kiedy wiara w Polszcze cała prosta i szczera była, tedy Polacy znali biskupów za ojców i pasterzy swoich»-w dawnych, dobrych czasach prostej wiary Sarmaci uważali kapłanów za duchownych przewodników, słuchali ich nauk (...) Nakłonienie słuchaczy, aby powrócili do tych praktyk zdaje się być jednym z podstawowych celów kazań (podkr. Ł.C.)." ${ }^{10}$ Nasycone wyżej wspomnianymi treściami utwory powstawać miały bez względu na to, czy istniał jakiś niezwykły pretekst (np. pojawienie się komety, wygrana bitwa), czy też nie, o czym świadczą obfite i cenne (wszak większość utworów nie doczekała się

\footnotetext{
9 op. cit., s. 13.

10 op. cit., s. 67.
} 
współczesnych edycji) przytoczenia w każdym z czterech głównych rozdziałów. Słowem, narzekania płynące $z$ ambony miały być praktyką powszechna, zdecydowanie dominującą nad pozytywną tendencją do dawania nadziei na odkupienie (co powodowało wspomnianą wyżej niewspółmierność oczekiwań nadawczo-odbiorczych). Aby zejść z drogi grzechu, która wiedzie nie tylko ku upadkowi osobistemu, lecz także ku unicestwieniu ojczyzny, powinno się podjąć najwyższe starania. Należało w tym celu wyzbyć się zepsucia moralnego, które zamiast maleć wraz z wypełnianiem określonych czynności symbolicznych (zwycięstwo militarne nad innowiercami, wypędzenie heretyków), rosło. Mówcy kościelni dążyli poniekąd do ukierunkowania zwróconej ku zdarzeniom zewnętrznym uwagi szlachty na jej życie wewnętrzne. Nakłaniali do rzetelnej introspekcji. Obecność heretyków stawała się (poza nielicznymi wyjątkami) raczej pretekstem do czynienia kolejnych wymówek (ich wyliczanie zajmuje główną cześć pracy) słuchaczom, których w cnocie prześcigają nawet wrogowie wiary, niż dawania nadziei na wieczną łaskę w zamian za przepędzenie „sprośnych pogańców”. W przedziale lat 1648-1660, wraz z narastaniem świadomości katastroficznej społeczeństwa oraz profetycznego tonu kazań, pojawiają się nawet głosy uderzające w mesjanizm oraz prowadzące do stwierdzenia, że szlacheckie rozumienie interesu państwowego może się kłócić z planem Bożym.

Rzeczone przytoczenia i refleksje faktycznie nie wydają się w najmniejszym nawet stopniu pretendować do grona elementów kształtujących mentalność sarmacką; bez wątpienia, punkt po punkcie negują każdą jej cechę, co sprawia, że w efekcie z fragmentów wyłania się postać szlachcica à rebours, a jedynym elementem jego świadomości kształtowanym przez kaznodziejów mogła być specyficzna wiara w opatrzność, oparta na zależności: osobista moralność - dobro państwa. Mimo uchybień warsztatowych (prowadzących do podważenia głównej tezy publikacji) Rzeczpospolitq oskarżanych narodów potraktować należy jako wołanie o rozleglejsze badania, które skupić się teraz powinny przede wszystkim na szlachcie, znajdujących się na jej ustach ideach, sposobie, w jaki były one powtarzane i przetwarzane na ambonach i nie tylko oraz na strategiach perswazyjnych realizo- 
wanych przez oracje. Omawiana praca stanowi jedynie punkt wyjścia czy raczej odniesienia. Zastanawiający jest bowiem jednowymiarowy obraz szlachcica-sarmaty, który nie ulega żadnym przekształceniom w miarę rozwoju refleksji nad kolejnymi etapami historycznego rozwoju stulecia. Doskwiera więc brak symultanicznego przedstawienia przemiany mentalności szlacheckiej. Przecież naczelny problem dotyczy właśnie „stawania się” sarmaty. W świetle refleksji nad prozą oratorską, już nie tylko katolicką, lecz także świecką, wciąż bez odpowiedzi pozostają pytania o źródło owego znamiennego dla XVII wieku samousprawiedliwienia. Trzeba przede wszystkim rozstrzygnąć, czy zasadne jest kierowanie ich w stronę wytworów sztuki mówniczej, czy też należy w nich szukać jedynie wynikających z pewnych zjawisk konsekwencji, które prowadzą do zupełnie innych wniosków niż spodziewane w powyższych (jak i powyższym podobnych ${ }^{11}$ ) rozważaniach. Jest to przede wszystkim problem doboru tekstów - sprawa istotna, domagająca się jasnych (choć nie zawsze możliwych do osiagnnięcia) rozgraniczeń genetycznych, której poświęcić należałoby osobną rozprawę.

${ }_{11}$ Zob. M. Brzozowski, Teoria kaznodziejstwa, [w:] Dzieje teologii katolickiej w Polsce, T. 2, cz. 1, Lublin 1975. Warto przy okazji zwrócić uwagę na paralelność pracy ks. Brzozowskiego i Roberta Kościelnego, który, jak sądzę, poszerzył jedynie materiał egzemplifikacyjny i postanowił obejrzeć go pod określonym kontem, zawężając zakres badań do jednej epoki. 